\title{
Price Sensitivity Measurement: A Yield Management Approach*
}

\author{
Okan Çolak1 ๑), Levent Koşan2 ๑
}

\begin{abstract}
The purpose of this paper is to investigate and identify the potential revenue losses, at price points determined by price sensitivity measurement, between actual revenue and potential revenue that can be gained, in terms of yield management. A case study was carried out in a 5 star hotel business in Aydın, Turkey. In the study, a questionnaire was conducted to determine price resistance levels, price threshold limits, price sensitivity levels and price perceptions based on the room quality perceptions of the tourists visiting the hotel business. Also, an interview was performed with the accounting manager and the front office manager about the room prices determined. Hotel businesses can determine the optimal price by depending on the quality and value perception of the customers; thus they can use their limited capacity more efficiently so that they can maximize yield. This study showed that the hotel business lost room revenue at all points calculated. The hotel business suffered a potential loss of $35-40 \%$ because of the high occupancy rate in July and August. The hotel industry could have room sales revenues much more than the actual room sales revenues, especially if the agency commission expenses can be reduced.
\end{abstract}

\section{Keywords}

Yield management, Price Sensitivity Measurement, Willingness-to-pay, All Inclusive System, Hotel Management

\section{Introduction}

Customers decide to buy according to their thoughts about perceived value and what the current price should be rather than the price stated by the businesses (Kotler and Keller, 2012). Moreover, the price is a criterion indicating the potential customers" "willingness to pay" for a product/service. Also, the price sensitivity of tourists is high, especially in hotel businesses. Therefore, customers' willingness to pay and price sensitivities must be taken into account when making a pricing decision (Ay1k et al., 2013; SMS, 2008). Since businesses do not have precise information about the market price, and the price will not be determined by

\footnotetext{
* This article is derived from a Ph.D. thesis entitled "Integration of Price Sensitivity Measurement and Quality Cost Management into the Target Costing Process in All-Inclusive System: An Application in a Hotel Enterprise"

1 Corresponding Author: Okan Çolak (Asst. Prof. Dr.), Harran University, School of Tourism and Hotel Management, Recreation Management Department, Sanliurfa, Turkey. E-mail: okancolak@harran.edu.tr ORCID: 0000-0001-7104-5853

2 Levent Koşan (Assoc. Prof. Dr.), Mersin University, Faculty of Tourism / Tourism Management, Mersin, Turkey.

E-mail: Ikosan@mersin.edu.tr ORCID: 0000-0001-7630-6354

To cite this article: Colak, O., \& Kosan, L. (2021). Price Sensitivity Measurement: A Yield Management Approach. Istanbul Business Research. Advance online publication. http://doi.org/10.26650/ibr.2021.51.0073
} 
the trial and error method, it is essential to conduct price research to determine the correct price (Grigsby, 2015).

Thanks to price research, business get information on how to price their products, how sales will drop when product prices increase, which market will be protected or lost when price changes, whether price discrimination is necessary or not to increase sales (Lipovetsky et al., 2011). Moreover, as a result of price research, businesses can follow a proactive pricing approach, i.e., they can see how pricing decisions affect buyers' perception of price and their perception of value. In this way, businesses can decide more effectively while increasing prices and making discounts (Monroe and Cox, 2001). However, businesses can increase their profitability by calculating the product/service value through accurate estimation and measurement methods and by setting a price to reflect this value and following a pricing policy (Smith and Nagle, 2002). According to Donatello's (2013) doctoral thesis study, one of the most common price research methods is the Price Sensitivity Measurement (PSM) method. The PSM is an effective method in determining the price for existing products. (Grigsby, 2015).

With the PSM method, the acceptable price range, between the highest and the lowest price range, is determined, and the percentage of customers who want to purchase can be seen within this range. Since the relationship between price, quality and the value perceived by customers is also taken into account while determining the price with PSM, it can be utilized for demand forecasting and product development decisions (Harmon et al., 2007; Lewis \& Shoemaker, 1997; Raab et al., 2009a; Raab et al., 2009b). In the hospitality industry, price research is mostly used in the economic benefits (yield management) of pricing decisions, choosing pricing strategy, reference pricing (Parsa and Njite, 2004). This study describes the potential revenue losses, at price points determined by price sensitivity measurement, between actual revenue and potential revenue that can be gained, in terms of yield management.

\section{The Price Sensitivity Measurement}

Price sensitivity measurement (PSM), developed by Dutch Economist Peter H. Van Westendorp, is defined as a method that measures the price perception to determine price resistance levels depending on the customers' perceptions of quality related to the product (Travis, 1982). Due to the connection that customers establish between the cost and benefit of the goods/services they want to buy, there are always low and high price thresholds in consumers' minds (Hoffman and Bateson, 2010). Most of the time, customers can give up their purchasing action when they perceive the brand they know as too expensive. On the other hand, if the price of the product is too low, they can doubt its quality-related features (Salamandic et al., 2015). When customers learn more about a product, they can change the acceptable price range. For example; If customers notice the existence of similar alternative offers, the upper 
price threshold is lower. However, if customer satisfaction or customer loyalty increases, the upper limit tends to increase. Conversely, if customer satisfaction or customer loyalty decreases, upper price thresholds also decrease (Monroe and Cox, 2001). The PSM method provides tips on understanding how the interaction of price and quality affects customers' perceptions of value and how to change their perceptions of value (Lewis and Shoemaker, 1997).

In the PSM method, the price is determined by asking questions about the products or services from different price perspectives and comparing them. The following four questions are asked within the scope of the method (Chhabra, 2015; Lipovetsky et al., 2011; SMS, 2008; Weiner, 2002; Westendorp, 1976):

1. At what price would you consider the product/service is so cheap that you would have some doubts about its quality, and you would not buy it? (Very cheap)

2. At what price would you consider the product/service is cheap, and you have no doubts about its quality, and you would buy the product/service? (Cheap)

3. At what price would you consider the product/service is expensive, but you would keep buying because of its good quality? (Expensive)

4. At what price would you feel the product/service is too expensive that it is not worth purchasing regardless of its good quality? (Very expensive)

With the PSM analysis, various points are obtained by combining the graphical curves created according to the cumulative values of the answers given to these 4 questions. These are Optimal Price Point (OPP). Point of Marginal Cheapness (PMC), Point of Marginal Expensiveness (PME), Indifference Price Point (IDP), Stress Price Range (SPR) and Range of Acceptable Price (RAP).

Optimal Price Point (OPP): The Optimal Price Point (OPP) is the price point at which the number of customers who perceive the product as very cheap is equal to the number of customers who recognise the product as very expensive. This is generally the recommended price (Hague, 2009). The word "optimal" in the OPP means that consumers have the least resistance to the product price (Westendorp, 1976). So, this point is the ideal price point for the product (Weiner, 2002).

Point of Marginal Cheapness (PMC): An equal number of participants evaluate the price offer as "very cheap - expensive at the Point of marginal cheapness (PMC) (SMS, 2008). PMC represents the lowest limit of the range of acceptable price (Weiner, 2002). Prices below this threshold force customers to question product quality and purchase decisions (Harmon et al., 2003). In this context, when the product underprices from this point, sales may decrease because of doubts about its quality (Lieberman, 2015). Therefore, the operating income will decrease even if the sales volume increases (SMS, 2008). 
Point of Marginal Expensiveness (PME): The Point of Marginal Expensiveness is the price point that the customer perceives the product price as too expensive according to the product value (Lieberman, 2015). An equal number of participants evaluate the price offer as "very expensive - cheap" at this point (SMS, 2008). PME represents the upper pricing threshold of the acceptable price range (Weiner, 2002). The prices above this threshold will cause the perceived value to decrease so low that consumers may prefer other products (Harmon et al., 2003). Moreover, a higher price will decrease sales volume and revenue. (SMS, 2008).

Indifference Price Point (IDP) and Indifference Price Percentage (IPP): The indifference price point (IDP) is the price point where the number of customers who perceive the product as cheap is equal to the number of customers who recognise the product as expensive. According to Van Westendorp, the price at this point generally represents either the average price paid by customers in general or the price of a significant market leader product (Hague, 2009). The potential profit will be lost when the product/service price is lower below IDP. On the other hand, more pricing above IDP will cause a decrease in sales volume (Weiner, 2002).

Van Westendorp (1976) states that the indifference price percentage (IPP) can be either so low (e.g. 5-15\%) or very high (e.g. 30\%). There is an inverse relationship between the indifference price percentage and price awareness. While a low IPP indicates a high price awareness, a high IPP indicates a low price awareness. On the other hand, when testing new products, businesses generally find higher values for the indifference price percentage.

Stress Price Range (SPR): The range between the optimal price point (OPP) and the indifference price point (IDP) is described as the stress price range. Van Westendorp (1976) states that the range between OPP and IDP is short in most cases. He even emphasizes that prices at these two points can be equal. Prolonged stress price range shows that there is some pressure/stress in price consciousness. When the OPP takes place to the left of the IDP or a lower OPP, it means that some customers have high price awareness and prefer a lower price. This situation usually occurs after a significant price increase. Conversely, an OPP higher than the IDP and below the upper price limit indicates that some customers may be willing to accept a price increase (Harmon et al., 2003).

Range of Acceptable Price (RAP): Price limits are described as price points where customers' thoughts become negative, and they may change their attitudes, purchase intentions and behaviours (Harmon et al., 2007). The acceptable price range is the price range between which customers suspect the quality of a brand, and consider it too high. In the prices outside this price range, the customers search for a replacement product/service (Travis, 1982). The price range between the point of marginal cheapness (PMC) and marginal expensiveness (PME) is the acceptable price range (RAP) for a product/service.

The Relationship Between Price Sensitivity Measurement and Yield Management 
Besides, yield management is a new management approach, and it is a crucial innovation, especially for service businesses (Netessine and Shumsky, 2002). In service businesses, it is of great importance to manage demand, especially since the airline companies, hotel businesses, cruise ships, restaurants, and entertainment centres have a limited capacity and are not able to increase these capacities in the short term. Also, because the products offered by service businesses cannot wait for a sale in the future, they lose all their value when not sold (Okumuş, 2004). As yield management is based on the principle of increasing revenue with the current capacity, it finds a more prominent place in service businesses (Farrel and Whelan-Ryan, 1998).

Yield management includes price adaptations and sales-related practices to maximize revenue from limited products and services of businesses with a fixed capacity (Koide and Ishii, 2005). Yield management has two essential objectives in terms of hotel businesses. These are determining the room price as to obtain maximum profit in periods when demand exceeds supply, and increasing occupancy by offering average room price in periods when demand is low compared to the amount of supply (Jones and Hamilton, 1992). For this reason, correct pricing has a vital place in yield management. The primary purpose of pricing is to obtain the highest profit and income by selling the products and services at the highest price that the current market segments will accept and are willing to pay (Jones, 2013). In this respect, yield management describes differentiation according to the increase and decrease in demand (Özel et al., 2012).

Price is not only crucial for achieving targeted profit but also for making targeted sales revenue (Blythe, 2005). Although business managers want to sell their business capacity at the highest price as possible, this is rarely applicable (Kimes, 1989). If the price is determined high, it may lead to a decrease in the demand for the business, which results in the termination of sales. On the other hand, when the price is too low, a negative opinion may occur about the product in terms of quality. This situation leads to a decrease in operating income and causes financial loss for the business. Therefore, business managers should set a price that will increase their profitability and take into consideration that determined price is in line with product quality, competitors' product prices, production costs and customers' willingness to pay (Burnett, 2008; Çetiner, 2002; Mirze, 2010).

Yield management provides a balance between demand and price (Kimes, 1989). So, yield management deals with both selling the right product to the right customer at the right time and aiming to achieve a high-profit margin by selling these products to customers who are willing to pay high prices. However, if businesses expect high value-added customers to meet their demands, the product sales period may end. As a result of this, there may be idle capacity, or companies may have to sell at low prices (Bitran and Caldentey, 2003).

In keeping with the yield management theory, the majority of hotels use dynamic pricing (Abrate et al., 2012; Mattila and Choi, 2014). The common subject of yield management and 
dynamic pricing is to create the opportunity to increase profits by applying different prices according to customer value perceptions (Jallat and Ancarani, 2008). For example, Abrate et al. (2019) used a new hedonic revenue model on a sample of 21,687 observations, and they found that a higher dynamic price variability leads to higher hotel revenues.

It is now common for hotels to charge different prices for the same room type, depending on the days of the week, duration of stay and prior reservation. Sometimes the same customers are charged different prices by the same hotel for different periods of stay. However, these pricing practices can alienate customers due to the perception of unfairness (Choi and Mattila, 2004). Kahneman et al. (1986) and Kimes and Wirtz (2002) stated that if the price differences are seen as unfair, the business may lose revenue because the customers do not agree to pay. Choi and Mattila (2004) concluded that hotel revenue management practices might lead to a perception of injustice, as a result of their study with 240 participants waiting to board an aeroplane at domestic gates of an airport located in Washington. On the other hand, Emeksiz et al. (2006) highlight that customers who buy rooms at high prices may think that they are being ripped off and therefore, they can change their purchasing decisions to another business. That's why they stress it is essential to understand how customers will react to a wide variety of prices for the same room. Also, Hanks et al. (2002) emphasise that customer groups' behaviour patterns and willingness to pay should be taken into account when making price differentiation. Yield management principally suggests segmenting customers according to their price sensitivity and willingness to pay, and then pricing. Despite unfairness concerns, Choi and Mattila (2004) pronounce that the question of how hotel yield management practices affect customer responses remains unanswered. In the study, price sensitivity measurement method has been proposed to solve these constraints in yield management.

The price sensitivity measurement method (PSM) focuses on finding an acceptable price as a quality indicator. PSM also takes into account consumers' both low-quality concerns due to low prices and concerns about very high pricing (Lipovetsky et al., 2011). Moreover, the method focuses on customer value perceptions which give consumers direct information on the pricing decision (Harmon et al., 2007). It assumes that consumers are willing to pay more for a better quality product (Weiner, 2002). So the method eliminates the sensitivities of the potential demand change that may occur as a result of pricing in yield management. Because in the PSM method, products are priced by taking into consideration factors such as price sensitivity, willingness to pay and value perception of customers. In addition to this, the method provides information about minimum and maximum prices which can be determined based on demand changes. Thanks to the method, businesses price their products more effectively and use their limited capacity more efficiently, so that they maximize the yield. 
Table 1

Literature Review

\begin{tabular}{|c|c|c|c|c|c|}
\hline Author/s & Date & Title & Sample & Findings & Implications \\
\hline $\begin{array}{l}\text { Lewis and } \\
\text { Shoemaker }\end{array}$ & 1997 & $\begin{array}{c}\text { Price-Sensitivity } \\
\text { Measurement: A Tool For } \\
\text { The Hospitality Industry }\end{array}$ & $\begin{array}{l}\text { The association } \\
\text { meeting market }\end{array}$ & $\begin{array}{l}\text { The study showed that } \\
\text { the PSM method could } \\
\text { be applied to the hotel } \\
\text { industry. }\end{array}$ & $\begin{array}{l}\text { Instead of using gut } \\
\text { feeling or trial and } \\
\text { error to determine the } \\
\text { right price for products/ } \\
\text { services, a hotel/ } \\
\text { restaurant owner can } \\
\text { use the PSM method, } \\
\text { a simple survey tool } \\
\text { to pre-measure the } \\
\text { price sensitivity of } \\
\text { customers. }\end{array}$ \\
\hline $\begin{array}{l}\text { Harmon } \\
\text { et al. }\end{array}$ & 2003 & $\begin{array}{c}\text { Incorporating Price } \\
\text { Sensitivity Measurement } \\
\text { İnto The Software } \\
\text { Engineering Process }\end{array}$ & $\begin{array}{l}96 \text { small-to- } \\
\text { medium sized } \\
\text { contractors }\end{array}$ & $\begin{array}{l}\text { The business should } \\
\text { first develop the labour } \\
\text { monitoring module for } \\
\text { faster financial gain. }\end{array}$ & $\begin{array}{l}\text { The PSM method } \\
\text { provides product } \\
\text { developers with } \\
\text { the ability to } \\
\text { quickly evaluate the } \\
\text { acceptable price range, } \\
\text { indifference points, } \\
\text { and optimum pricing } \\
\text { points for any software } \\
\text { configuration. }\end{array}$ \\
\hline Raab et al. & 2009 & $\begin{array}{l}\text { Activity-based pricing: } \\
\text { can it be applied in } \\
\text { restaurants? }\end{array}$ & $\begin{array}{c}\text { Hong Kong } \\
\text { buffet restaurant }\end{array}$ & $\begin{array}{l}\text { The study showed } \\
\text { that although guests } \\
\text { are relatively price- } \\
\text { insensitive, drastic } \\
\text { measures are needed } \\
\text { to make the restaurant } \\
\text { profitable by reducing } \\
\text { costs. }\end{array}$ & $\begin{array}{c}\text { Utilizing activity based } \\
\text { pricing (Activity- } \\
\text { based costing and } \\
\text { the PSM method) } \\
\text { allows a restaurant } \\
\text { truly to understand } \\
\text { both its operating cost } \\
\text { structure and the price } \\
\text { perceptions of it guests. }\end{array}$ \\
\hline Raab et al. & 2009 & $\begin{array}{c}\text { Price-Sensitivity } \\
\text { Measurement: A Tool For } \\
\text { Restaurant Menu Pricing }\end{array}$ & $\begin{array}{c}\text { Hong Kong } \\
\text { buffet restaurant }\end{array}$ & $\begin{array}{l}\text { The results reveal price } \\
\text { ranges that represent } \\
\text { real value for dinner } \\
\text { buffet customers. }\end{array}$ & $\begin{array}{c}\text { Restaurant managers } \\
\text { can obtain information } \\
\text { about menu prices } \\
\text { directly from their } \\
\text { customers through } \\
\text { a relatively simple } \\
\text { survey. }\end{array}$ \\
\hline
\end{tabular}

As a result of the study, the indifference price point was found different in three different countries. Also, they found that the price that maximizes turnover and the profit differs from indifference price.
Authors proposed a model to use the PSM method to maximize profit and income. 


\begin{tabular}{|c|c|c|c|c|c|}
\hline $\begin{array}{l}\text { Salamandic } \\
\text { et al. }\end{array}$ & 2014 & $\begin{array}{c}\text { Price sensitivity } \\
\text { measurement depending } \\
\text { on brand awareness: a } \\
\text { case } \\
\text { of Ziede brand }\end{array}$ & $\begin{array}{l}\text { All girls and } \\
\text { women in } \\
\text { Lithuania from } \\
11 \text { to } 35 \text { years } \\
\text { old }\end{array}$ & $\begin{array}{l}\text { The results of the } \\
\text { study confirm that } \\
\text { the optimal price } \\
\text { determined differs } \\
\text { between brand- } \\
\text { conscious and unaware } \\
\text { customers. }\end{array}$ & $\begin{array}{l}\text { The optimal price } \\
\text { determined for brand- } \\
\text { conscious consumers } \\
\text { protects the brand } \\
\text { value, and the business } \\
\text { can make additional } \\
\text { profit. }\end{array}$ \\
\hline $\begin{array}{l}\text { Ceylana } \\
\text { et al. }\end{array}$ & 2014 & $\begin{array}{l}\text { Value Based Pricing: } \\
\text { A Research on Service } \\
\text { Sector using Van } \\
\text { Westendorp Price } \\
\text { Sensitivity Scale } \\
\end{array}$ & $\begin{array}{c}200 \\
\text { students of Usak } \\
\text { University }\end{array}$ & $\begin{array}{l}\text { The study showed that } \\
\text { the price sensitivity of } \\
\text { the university students } \\
\text { on private dormitories } \\
\text { is high. }\end{array}$ & $\begin{array}{c}\text { PSM method is used as } \\
\text { a value-based pricing } \\
\text { method. }\end{array}$ \\
\hline Chhabra & 2015 & $\begin{array}{l}\text { Determining the Optimal } \\
\text { Price Point: Using Van } \\
\text { Westendorp's Price } \\
\text { Sensitivity Meter }\end{array}$ & $\begin{array}{l}\text { Females within } \\
\text { the age group of } \\
20-35 \text { years, }\end{array}$ & $\begin{array}{c}\text { The optimal price point } \\
\text { determined as Rs. } 190 \\
\text { for } 250 \mathrm{ml} \text { Vivel Cell } \\
\text { Renew. }\end{array}$ & $\begin{array}{l}\text { PSM analysis can } \\
\text { provide the first } \\
\text { indications of optimal } \\
\text { prices. However, } \\
\text { the method needs } \\
\text { to be changed and } \\
\text { completed to come } \\
\text { up with concrete } \\
\text { recommendations } \\
\text { in terms of price } \\
\text { management. }\end{array}$ \\
\hline Desmet & 2016 & $\begin{array}{l}\text { Effectiveness of measures } \\
\text { assessing response } \\
\text { to price information }\end{array}$ & $\begin{array}{l}\text { Internet panel } \\
\text { participants who } \\
\text { are responsible } \\
\text { for shopping for } \\
\text { their } \\
\text { household. }\end{array}$ & $\begin{array}{l}\text { Multiple questions } \\
\text { (price decisions and } \\
\text { repeated random } \\
\text { discrete choices) } \\
\text { increase interest in } \\
\text { price information and } \\
\text { reduce bias. }\end{array}$ & $\begin{array}{c}\text { Price judgments } \\
\text { provide reliable } \\
\text { information about } \\
\text { consumers' reactions to } \\
\text { prices. }\end{array}$ \\
\hline Hidalgo & 2017 & $\begin{array}{l}\text { Market Potential of } \\
\text { Pasteurized Coconut } \\
\text { Water in the Philippine } \\
\text { Beverage Industry }\end{array}$ & $\begin{array}{l}\text { The beverage } \\
\text { consumers }\end{array}$ & $\begin{array}{l}\text { In the study, } \\
\text { Pasteurized Coconut } \\
\text { Water was subjected } \\
\text { to price analysis } \\
\text { to measure price } \\
\text { sensitivity according } \\
\text { to consumer price } \\
\text { expectations and } \\
\text { threshold perceptions. }\end{array}$ & $\begin{array}{l}\text { In cases that may } \\
\text { affect the profitability } \\
\text { of the business, the } \\
\text { price should be within } \\
\text { the acceptable price } \\
\text { range. Otherwise, } \\
\text { the company may } \\
\text { experience the } \\
\text { consequences } \\
\text { of reversing the } \\
\text { purchasing decisions of } \\
\text { the consumer. }\end{array}$ \\
\hline $\begin{array}{l}\text { Khandker } \\
\text { and Joshi }\end{array}$ & 2019 & $\begin{array}{l}\text { Price determination for } \\
\text { 4G service using price } \\
\text { sensitivity model } \\
\text { in India }\end{array}$ & $\begin{array}{l}\text { The students } \\
\text { of an } \\
\text { internationally } \\
\text { accredited } \\
\text { business school } \\
\text { in a university } \\
\text { town }\end{array}$ & $\begin{array}{l}\text { The PSM identifies } \\
\text { the acceptable range } \\
\text { and the best price } \\
\text { points. The estimates } \\
\text { obtained are similar to } \\
\text { the current prices of } \\
\text { data packages in the } \\
\text { same telecom circle, } \\
\text { confirming the fit of the } \\
\text { PSM. }\end{array}$ & $\begin{array}{l}\text { For practitioners and } \\
\text { academics, this study } \\
\text { reveals the relevance } \\
\text { and utility of a direct } \\
\text { approach of the PSM } \\
\text { to estimate individuals } \\
\text { WTP' for a new } \\
\text { product/service. }\end{array}$ \\
\hline
\end{tabular}




\begin{tabular}{|c|c|c|c|c|c|}
\hline $\begin{array}{l}\text { Dominique- } \\
\text { Ferreira and } \\
\text { Antunes }\end{array}$ & 2020 & $\begin{array}{c}\text { Estimating the price range } \\
\text { and the effect of price } \\
\text { bundling strategies } \\
\text { An application to the } \\
\text { hotel sector }\end{array}$ & $\begin{array}{l}\text { Customers from } \\
\text { three- and five- } \\
\text { stars hotels }\end{array}$ & $\begin{array}{l}\text { Bundling strategy } \\
\text { results reveal that } \\
\text { five-star customers } \\
\text { are less susceptible to } \\
\text { mixed-leader bundling. } \\
\text { Regarding mixed } \\
\text { joint bundling sales, } \\
\text { managers can increase } \\
\text { sales through bundling } \\
\text { strategies if they choose } \\
\text { an attractive service } \\
\text { (e.g. restaurants). }\end{array}$ & $\begin{array}{l}\text { The findings help } \\
\text { hotel managers } \\
\text { understand different } \\
\text { price sensitivities } \\
\text { according to hotel } \\
\text { typology. Managers can } \\
\text { manage prices without } \\
\text { risking losing market } \\
\text { share or revenue. The } \\
\text { results help managers } \\
\text { decide what bundling } \\
\text { strategies they can } \\
\text { create and the services } \\
\text { to include to achieve } \\
\text { the highest profitability. }\end{array}$ \\
\hline Dong et al. & 2020 & $\begin{array}{c}\text { Urban households' } \\
\text { purchase intentions for } \\
\text { pure electric vehicles } \\
\text { under subsidy contexts } \\
\text { in China: Do cost factors } \\
\text { matter? }\end{array}$ & $\begin{array}{l}\text { Chinese urban } \\
\text { households from } \\
\text { eight economic } \\
\text { regions (or } 30 \\
\text { provinces) }\end{array}$ & $\begin{array}{l}\text { The acceptable price } \\
\text { range for all-electric } \\
\text { vehicles for urban } \\
\text { families is between } \\
65,000 \mathrm{CNY} \text { and } \\
120,000 \mathrm{CNY} \text {. }\end{array}$ & $\begin{array}{l}\text { PSM method has been } \\
\text { associated with cost } \\
\text { and purchase intention. }\end{array}$ \\
\hline
\end{tabular}

As can be seen in Table1, There are studies related to the price sensitivity measurement (PSM) method applied in different sectors for both existing and new products. Harmon et al. (2003) used the PSM method to determine the most appropriate price point and price threshold limits depending on the quality perceptions of a new software product. Salamandic et al. (2014) and (2015) used the PSM method to measure the price sensitivity of existing and new cosmetic products according to the brand awareness of customers in their studies. Similarly, Chabbra (2015) used the PSM method in pricing a cosmetic product. Khandker and Joshi (2019) used the PSM method to set a price for a telecom company's 4G service in India. Dong et al. (2020) used the PSM method to measure urban households' price preferences for a new product, purely electric vehicles.

In the hospitality industry, the PSM model was first used in 1988 at Taco Bell Fast Food to create a menu based on value-based pricing (Lewis \& Shoemaker, 1997). Similarly, Ceylana et al. (2014) used the PSM method as a value-based pricing tool to examine university students' price perceptions about private dormitories. Also, there are studies by Raab et al. (2009a) and (2009b) in the pricing of an evening buffet meal in a restaurant in Hong Kong. Moreover, Hidalgo (2017) used the PSM method to determine the ideal price for Pasteurized Coconut Water according to consumer price expectations and threshold perceptions. As a result of the literature review on PSM, no research was found regarding the determination of the room price in the all-inclusive system. However, there are studies by Dominique-Ferreira and Antunes (2020) in estimating the price range and the effect of price bundling strategies in the hotel sector and by Lewis and Shoemaker (1997) in determining the price of the room for the planned holiday on congress organization companies. 
Unlike their classic interpretation of the PSM method, Roll et al. (2010) first time interpreted with a new approach to maximize profitability and revenue. As a result of the study, the indifference price point was found different in three different countries. Also, they found that the price that maximizes turnover and the profit differs from indifference price. With this study, the relationship between price sensitivity measurement and yield management was investigated for the first time in the hospitality industry. In their studies, Dominique-Ferreira and Antunes (2020) also state that thanks to the PSM method, hotel managers have the opportunity to manage prices without the risk of loss of market and revenue. Also, they specified that the PSM results help managers decide an appropriate product to achieve the highest profitability. Similarly, Harmon et al. (2003) suggested that the enterprise should develop the labor monitoring module first for faster financial gain. Also, Salamandic et al. (2014) stated that the business would gain higher profits by turning to brand-conscious customers. Therefore, we can say that the results obtained in the PSM method can be used in managing demand and pricing decisions to maximize yield.

\section{Methodology}

A case study was carried out in a 5-star hotel business in Aydin. The hotel business provides accommodation in an all-inclusive concept and has 245 rooms and 650 beds capacity in total. The hotel business provides food and beverage service in a total of six units, including two restaurants, three bars, and one disco. The hotel has one outdoor pool, one children's pool, one indoor pool, and one aquapark. Also, the hotel has three meeting rooms. Within the all-inclusive concept, as an accommodation service, towel change is made once a day, beach towel change is free, linen change once every three days and room cleaning is done every day. There is a balcony, bathtub, hair dryer, direct telephone, wake-up service, safe deposit box, satellite TV, internet connection, split air conditioner, minibar, electronic lock system, fire alarm and 24-hour room service in the hotel rooms. Within the concept, customers can use the pools (outdoor, indoor and children's pool) and aquapark free of charge. Also, breakfast, lunch, dinner, snack, tea time and night soup are served free of charge. Besides, all drinks except imported alcoholic beverages are provided free of charge. The beverage service ends at 23:00, and after this time, drinks are sold as extra. Free activities and services are; Turkish bath, sauna, fitness centre, kids club, all animation activities, beach towels, sunbeds, sun umbrellas, baby beds, baby table chairs and ice cream time (for children).

In the study, a questionnaire was conducted to determine price resistance levels, price threshold limits, price sensitivity levels and price perceptions based on the all-inclusive pension service quality perceptions of the tourists visiting the hotel business. Also, an interview was performed with the accounting manager and front office manager about the room prices determined. 
As the case study method was used in the research, the research was limited to a hotel business. Also, the study was limited to July and August 2017. In the hotel business, it occurred a totally 15,968 overnight stays in July, and 16,917 overnight stays in August. Since it was not possible to reach the whole population in terms of both cost and time, sampling was used in the research. While calculating the sample, the number of overnight stays was taken into consideration, and the number of samples was determined by using the hypothetical sample size table (Balc1, 2011) for the different sized population. According to the table, the number of samples for each month was determined 381, with a 5\% margin of error. The convenience sampling method was selected from the non-probability sampling methods. In total, 450 questionnaires were conducted for July and August. Due to the incorrect questionnaire form and some of the questions that were not answered, 398 for July and 386 for August available questionnaires were obtained.

The questions developed by the Dutch economist Peter H. Van Westendorp (1976) were used to measure price sensitivity. Four questions were posed in this study to implement the PSM:

1. In this hotel, at what price would you consider the all-inclusive room price per person is too cheap so that you would question its quality and would not purchase it?

2. In this hotel, at what price would you consider the all-inclusive room price per person is cheap however you have no doubts about its quality and you would purchase it?

3. In this hotel, at what price would you think the all-inclusive room price per person is kind of expensive, but still worth buying because of its good quality (rooms, foods, activities etc.)?

4. In this hotel, at what price would you feel the all-inclusive room price per person is so expensive that it is not worth purchasing in this hotel regardless of its good quality (rooms, foods, activities etc.)?

The responses obtained from the four open-ended questions have been combined with the graphical curves generated depending on the cumulative frequencies, and the intersection points have been calculated. There are 5 units between price intersection values. Considering the intersection points for the two months, Point of Marginal Cheapness (PMC), Point Of Marginal Expensiveness (PME), Optimal Price Point (OPP), Indifference Price Point (IDP), Indifference Price Percentage (IPP), Range of Acceptable Price (RAP) and Stress Price Range (SPR) have been calculated. All prices displayed in the graphs are expressed in Turkish Liras. So, the prices stated in the form of currency in the questionnaire form was converted to TL. The buying rate of exchange declared by the Central Bank of the Republic of Turkey was taken into account. Then, the average of these exchange rates was calculated for July and 
August. The amounts converted to TL was rounded up or down to the nearest whole TL value (0-5). The exchange rate conversion rates for July were 3,5599 for USD, 0,0593 for RUBLE, 4,0914 for EURO and 4,6140 for GBP. And, the exchange rate conversion rates for August were 3,5125 for USD, 0,0585 for RUBLE, 4,11436 for EURO and 4,5512 for GBP. In terms of validity, the results obtained by the PSM method were discussed with the accounting manager and compared with the current sales prices of the hotel.

\section{Findings and Discussion}

\section{Price Sensitivitiy Measurement (PSM) Results}

Under this title, results take place about price resistance levels, price threshold limits, price sensitivity levels and price perceptions based on the room quality perceptions of the tourists visiting the hotel business.

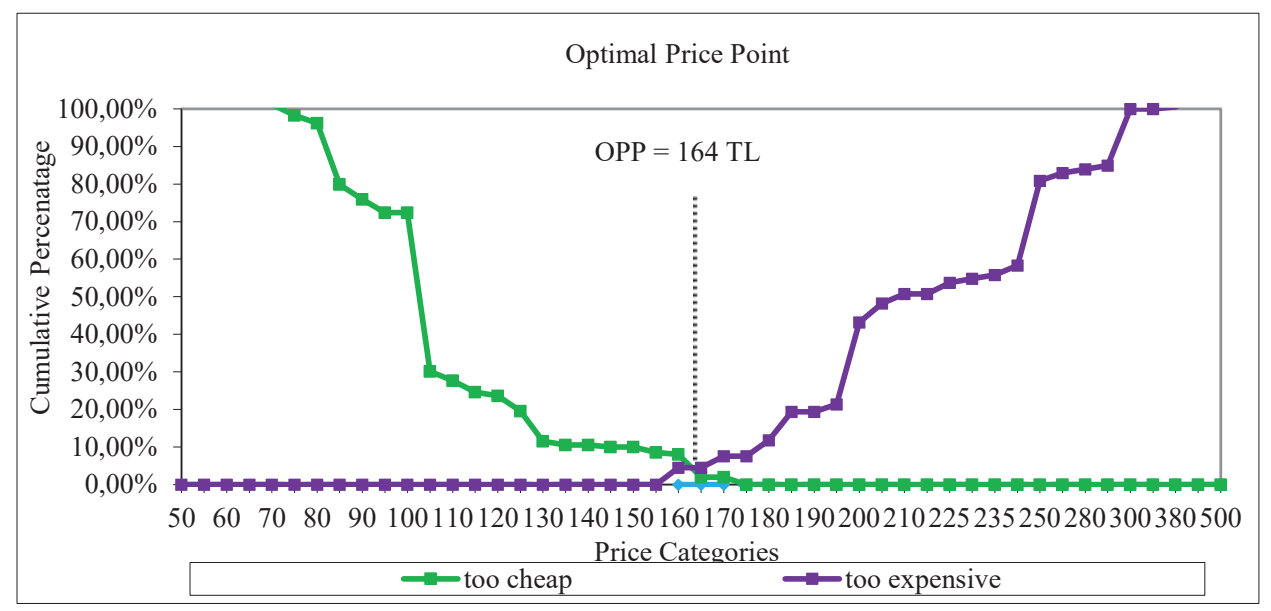

Figure 1. Optimal Price Point For All Inlusive Pension Per Person (July)

Figure 1 depicts the optimal price point (OPP) for all-inclusive pension per person in July. OPP was determined as 164 TL per person in July. 


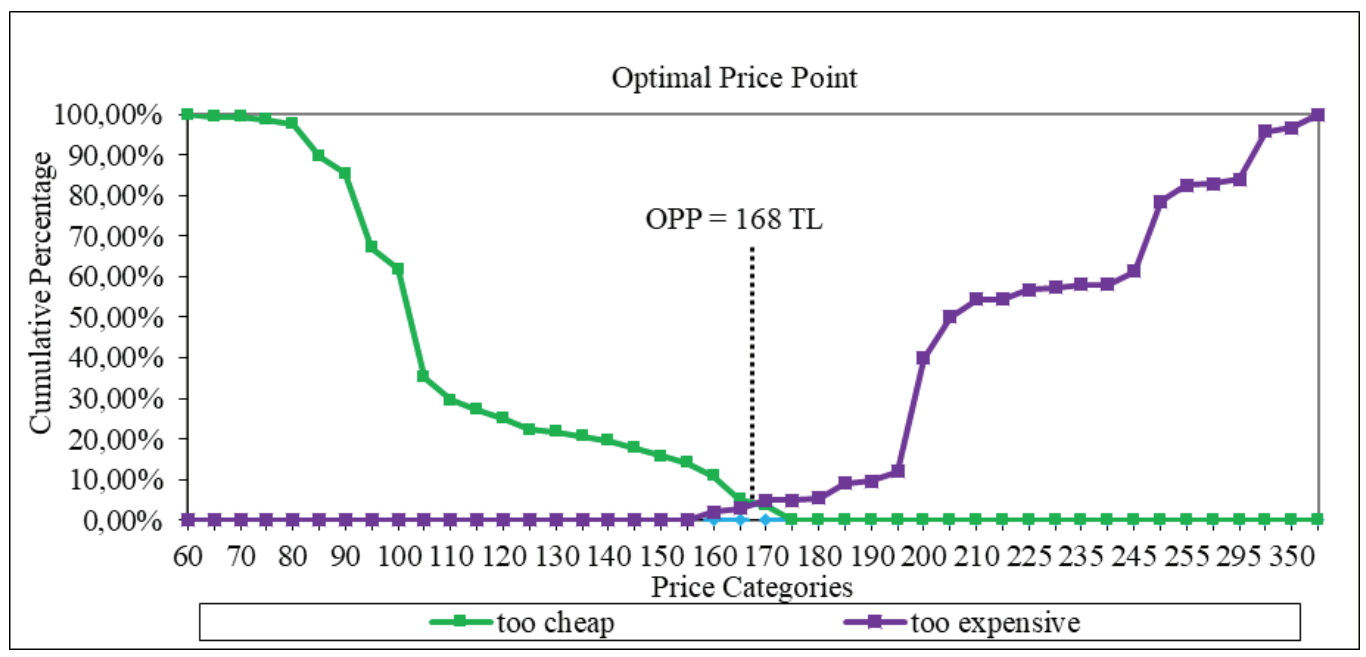

Figure 2. Optimal Price Point For All Inlusive Pension Per Person (August)

Figure 2 depicts the optimal price point (OPP) for all-inclusive pension per person in August. OPP was determined as $168 \mathrm{TL}$ per person in August.

The results illustrate that an optimal price point (OPP) which is much more than the actual room sales price per person. In terms of validity, the results obtained by the PSM method were discussed with the accounting manager and compared with the current sales prices of the hotel. During the meeting with the accounting manager; he stated that the optimal price was at market value and the surplus between the actual average selling price and OPP was due to discounts provided to the timeshare vacation customers and commission paid to travel agencies in particular. In this context, he emphasized that a $35-40 \%$ discount applied to timeshare vacation customers decreases the average actual sales price of the room. Also, he emphasized that as a result of the commission rates, the transfer, guidance fees and profit margin added by the travel agencies and tour operators, all-inclusive rooms per person were sold around $170 \mathrm{TL}-180 \mathrm{TL}$ and this caused the surplus. In addition to this, during the interview with the front office manager, he stated that they offer a $10-15 \%$ discount for repeat guests depending on silver and gold customer classification. 


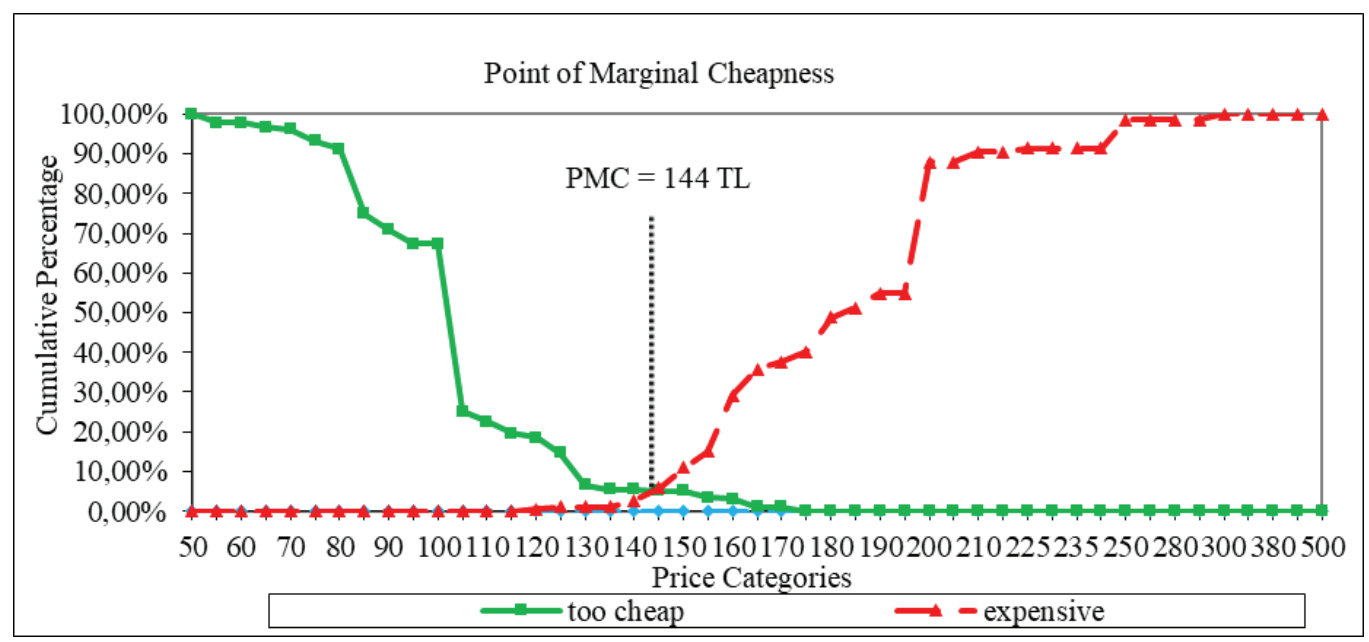

Figure 3. Point of Marginal Cheapness For All Inlusive Pension Per Person (July)

Figure 3 depicts the point of marginal cheapness (PMC) for all-inclusive pension per person in July. PMC was determined as 144 TL per person in July.

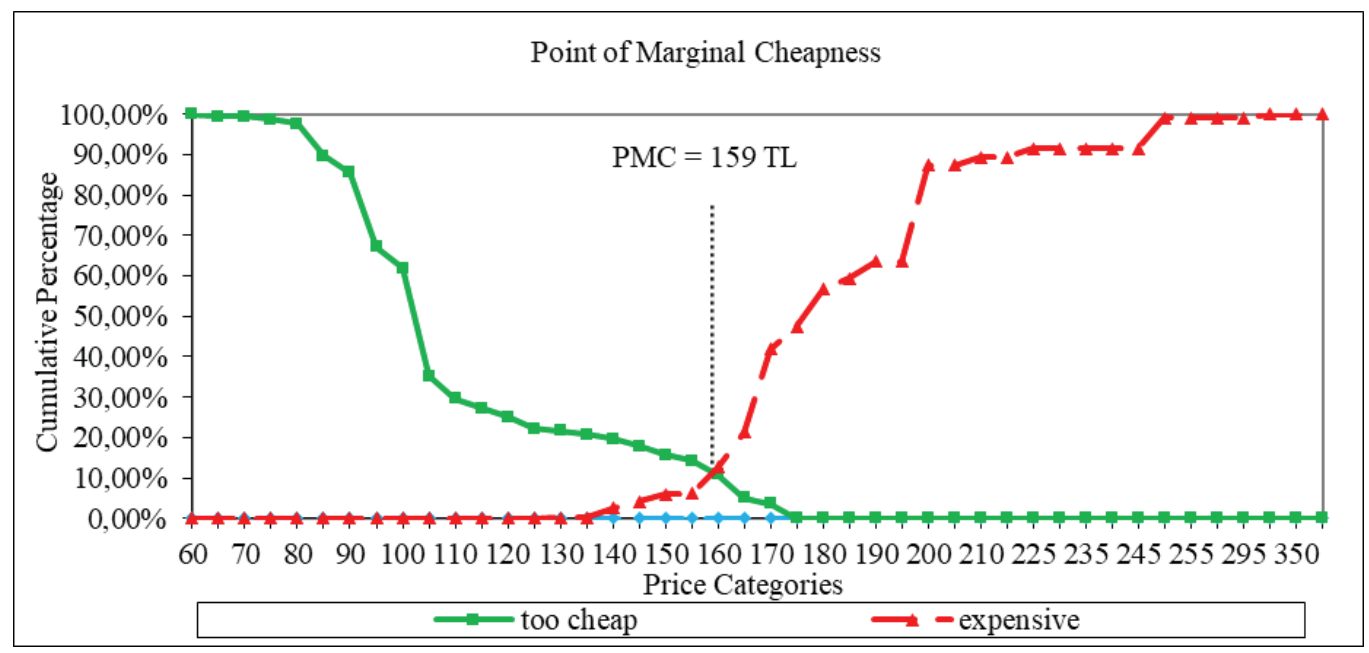

Figure 4. Point of Marginal Cheapness For All Inlusive Pension Per Person (August)

Figure 4 depicts the point of marginal cheapness (PMC) for all-inclusive pension per person in August. PMC was determined as 159 TL per person in August.

All-inclusive pension per person price has not to decrease below PMC points to ensure that customers do not doubt the quality of service provided and that sales and sales revenues of the entity do not decrease. The indifference price point (IDP) for all-inclusive per person 
was determined 155 TL for July (Figure 7) and 165 TL for August (Figure 8). Thus, it can be assumed that customers perceive the price range between 144 TL and 155 TL for July, and between 159 TL and 165 TL for August as cheap but without significant doubts about the quality of the service provided.

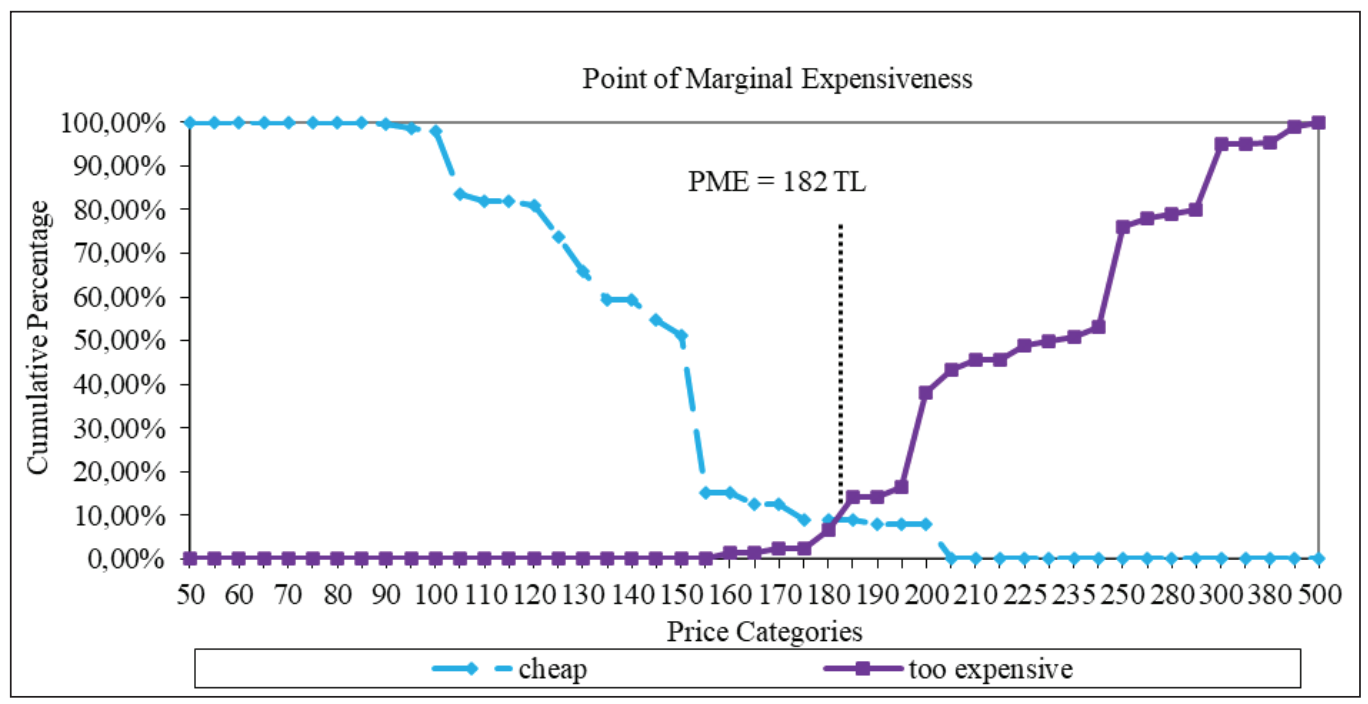

Figure 5. Point of Marginal Expensiveness For All Inlusive Pension Per Person (July)

Figure 5 depicts the point of marginal expensiveness (PME) for all-inclusive pension per person in July. PME was determined as 182 TL per person in July.

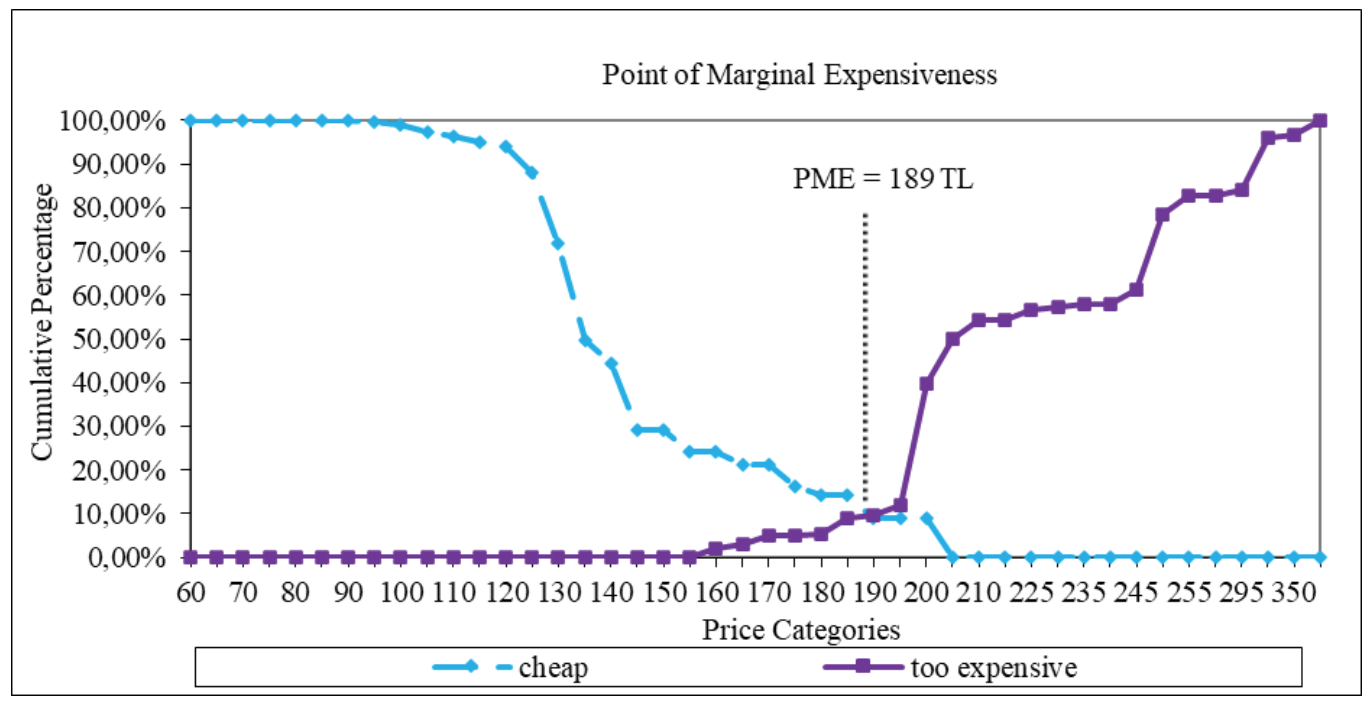

Figure 6. Point of Marginal Expensiveness For All Inlusive Pension Per Person (August) 
Figure 6 depicts the point of marginal expensiveness (PME) for all-inclusive pension per person in August. PME was determined as 189 TL per person in August.

Even if the businesses offer high service quality to customers, they should not set a price above PME points in order not to decrease sales and sales revenues, as customers can give up the decision to purchase. Also, the indifference price point (IDP) for all-inclusive per person was determined 155 TL for July and 165 TL for August. Although customers perceive the price range between 155 TL and 182 TL for July, and between 165 TL and 189 TL for August as expensive, they still recognise that it is worth it for the quality of service they receive.

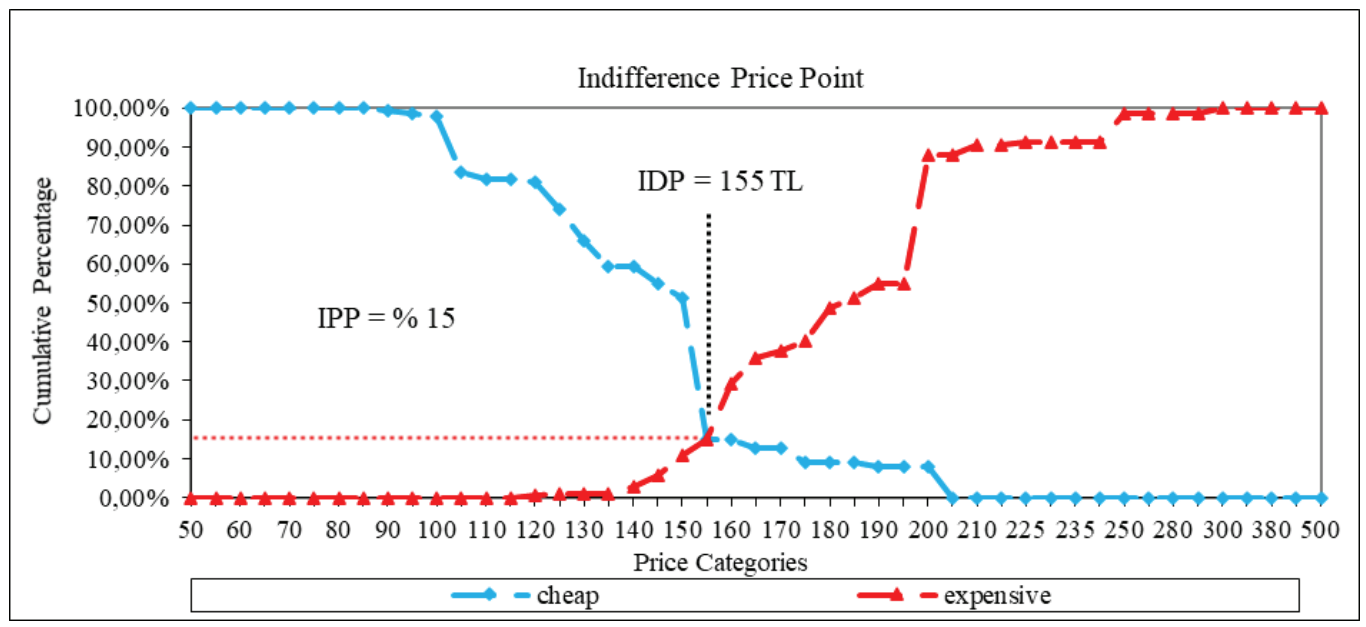

Figure 7. Indifference Price Point and Indifference Price Percentage For All Inlusive Pension Per Person (July)

Figure 7 depicts the indifference price point (IDP) and indifference price percentage (IPP) for all-inclusive pension per person in July. IDP was determined as 155 TL per person and IPP was determined as \%15 in July. According to IPP, the customers who prefer to stay in July have a medium-level price awareness. 


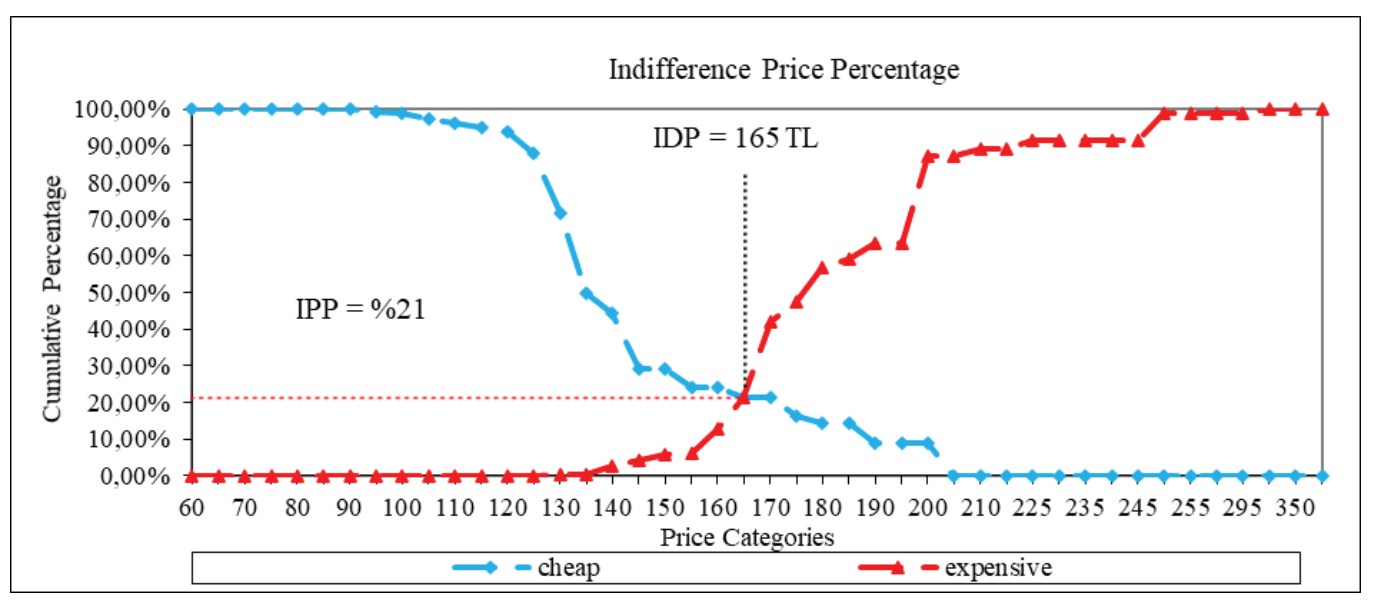

Figure 8. Indifference Price Point and Indifference Price Percentage For All Inlusive Pension Per Person (August)

Figure 8 depicts the indifference price point (IDP) and indifference price percentage (IPP) for all-inclusive persion person in August. IDP was determined as 165 TL per person and IPP was determined as \%21 in August. According to IPP, the customers who prefer to stay in August have a low-level price awareness.

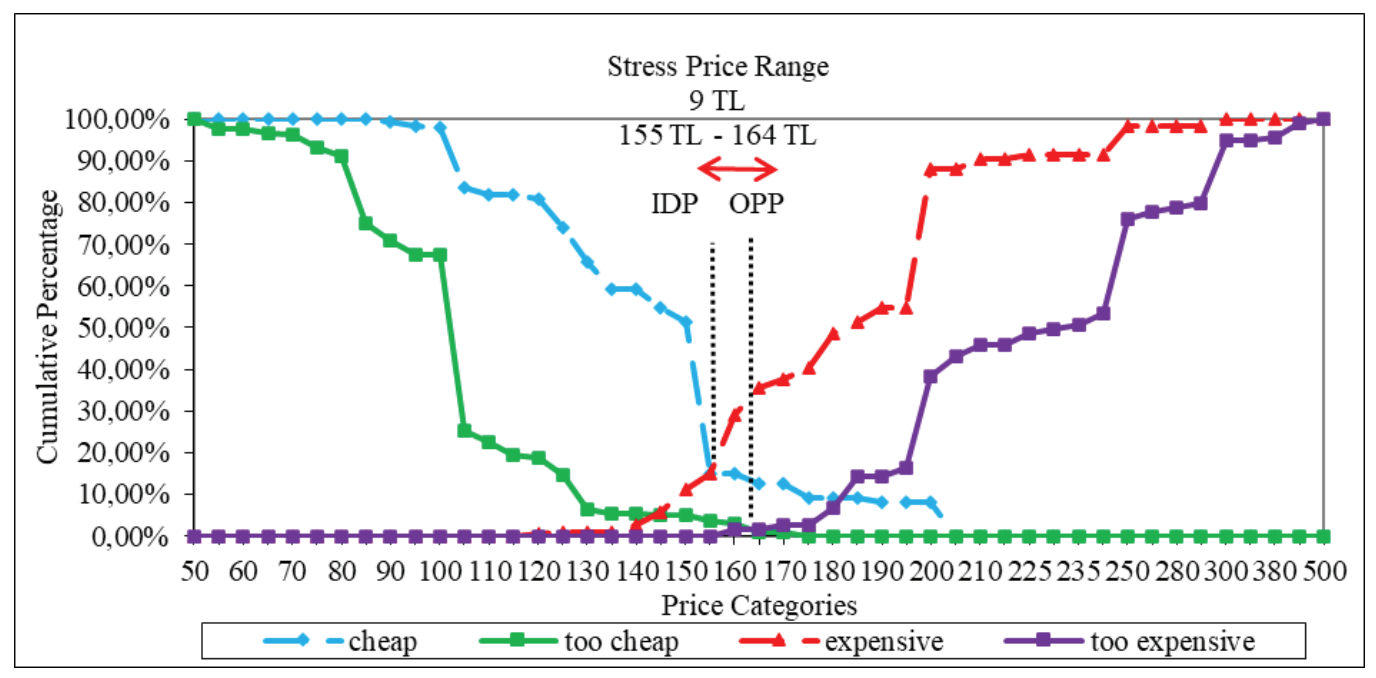

Figure 9. Stress Price Range For All Inlusive Pension Per Person (July)

Figure 9 depicts the stress price range (SPR) for all-inclusive pension per person in July. SPR was determined as 9 TL in July. 


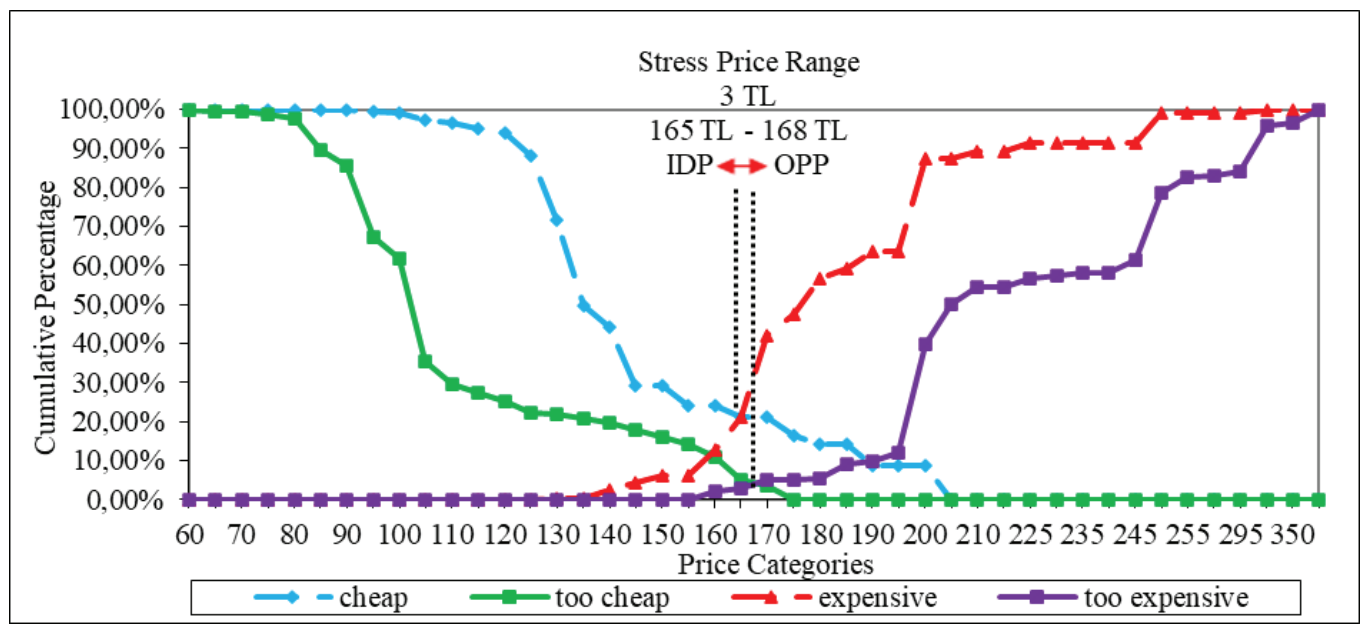

Figure 10. Stress Price Range For All Inlusive Pension Per Person (August)

Figure 10 depicts the stress price range (SPR) for all-inclusive pension per person in August. SPR was determined as 3 TL in August.

Both in July and August, OPP is on the right side of IDP and higher than IDP. This result means that the pressure on the price is low, and customers can pay more than the price at the IDP point. Also, the low price range of stress compared to the acceptable price range indicates that the price sensitivity of the customers is low.

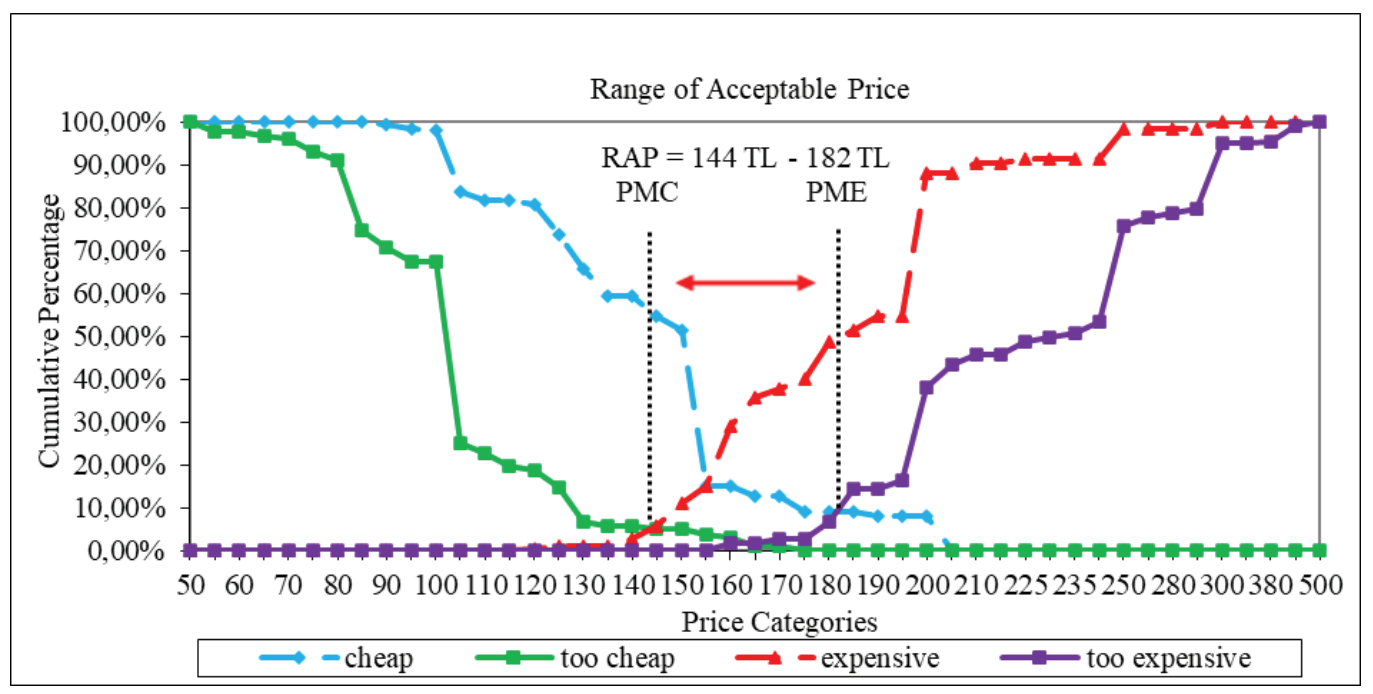

Figure 11. Range of Acceptable Price For All Inlusive Pension Per Person (July) 
Figure 11 depicts the range of acceptable price (RAP) for all-inclusive pension per person in July. According to the graphic, the business can set a minimum price of 144 TL and a maximum of 182 TL for all-inclusive per person.

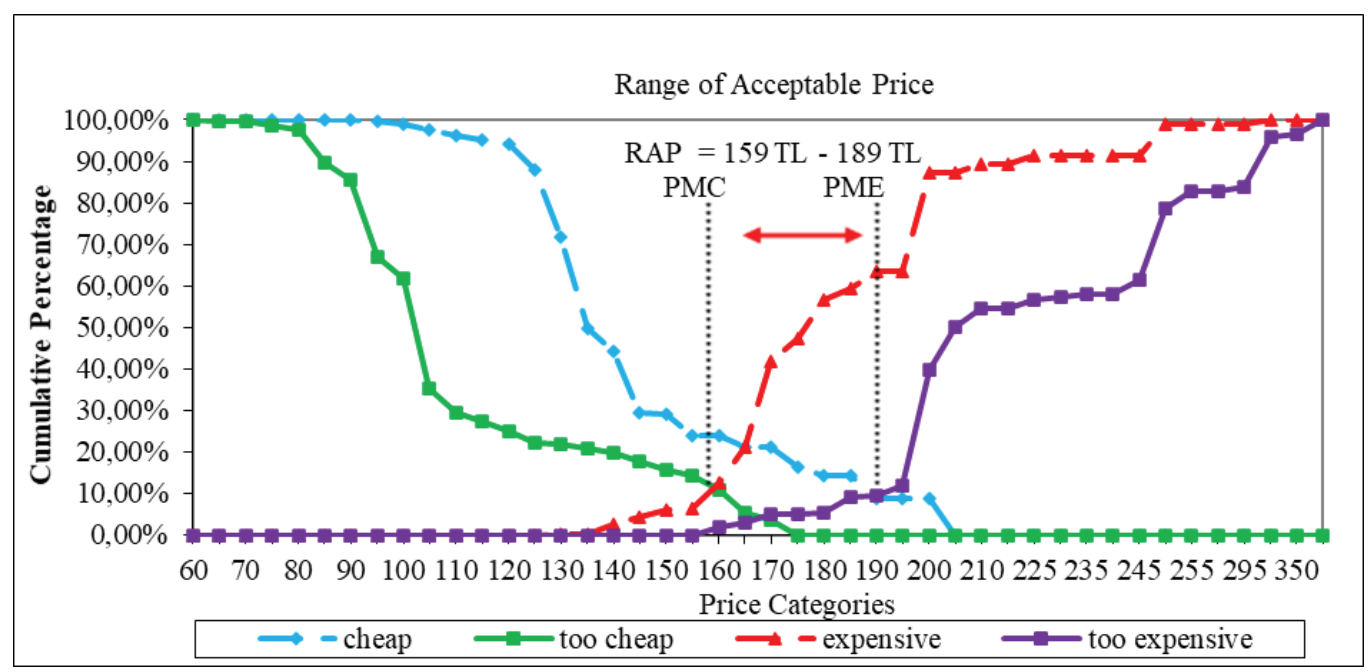

Figure 12. Range of Acceptable Price For All Inlusive Pension Per Person (August)

Figure 12 depicts the range of acceptable price (RAP) for all-inclusive pension per person in August. According to the graphic, the business can set a minimum price of $159 \mathrm{TL}$ and a maximum of 189 TL for all-inclusive per person.

The shorter acceptable price range depicts higher price sensitivity (Lewis and Shoemaker, 1997). In the study, the range of acceptable price is determined 38 TL for July and 30 TL for August. The wide range of acceptable price indicates that customers' price sensitivity is low.

\section{Potential Room Revenue Losses Calculated for All Points}

Under this title, results take place about potential room revenue loss calculated for all points. Table 2 shows the room revenues in the hotel business in July and August, the number of overnight stays, the current room sales prices, PSM analysis results and the potential room sales revenue losses calculated according to the all points determined. All-inclusive services are billed together with the overnight stay and subject to $8 \%$ VAT within the scope of the overnight stay in all-inclusive hotels (K1z1lot, 2008). Therefore, the VAT rate was taken $8 \%$ in the room sales price calculations. 
Table 2

Potential Room Revenue Losses Calculated for All Points

\begin{tabular}{lcc}
\hline Annual Report Data & July & August \\
\hline a) Room Revenues & $1.797 .579,66 \mathrm{TL}$ & $1.924 .609,08 \mathrm{TL}$ \\
b) Overnight Stays & 15.968 & 16.917 \\
c) Actual Room Rate For All Inclusive Pension Per & & $122,87 \mathrm{TL}$ \\
Person & $121,58 \mathrm{TL}$ & August \\
(\%8 VAT Included) (a/b)*1,08 & July & $168,00 \mathrm{TL}$ \\
\hline PSM Analysis Results & $164,00 \mathrm{TL}$ & $159,00 \mathrm{TL}$ \\
\hline d) Optimal Price Point (OPP) & $144,00 \mathrm{TL}$ & $189,00 \mathrm{TL}$ \\
e) Point of Marginal Cheapness (PMC) & $182,00 \mathrm{TL}$ & $165,00 \mathrm{TL}$ \\
f) Marginal Expensiveness (PME) & $155,00 \mathrm{TL}$ & $\% 21$ \\
g) Indifference Price Point (IDP) & $\% 15$ & $165 \mathrm{TL}-168 \mathrm{TL}$ \\
h) Indifference Price Percentage (IPP) & $155 \mathrm{TL}-164 \mathrm{TL}$ & $159 \mathrm{TL}-189 \mathrm{TL}$ \\
i) Stress Price Range (SPR) & $144 \mathrm{TL}-182 \mathrm{TL}$ & August \\
j) Acceptable Price Range (RAP) & July & $706.911,31 \mathrm{TL}$ \\
\hline Potential Room Revenue Losses & $627.187,56 \mathrm{TL}$ & \\
\hline k) For Optimal Price Point (OPP) & & $565.936,31 \mathrm{TL}$ \\
[b*(d-c)]/1,08 & $331.483,85 \mathrm{TL}$ & $1.035 .852,97 \mathrm{TL}$ \\
1) For Point of Marginal Cheapness (PMC) & & $659.919,64 \mathrm{TL}$ \\
[b*(e-c)]/1,08 & $494.120,89 \mathrm{TL}$ & \\
m) For Point of Marginal Expensiveness (PME) & & \\
[b*(f-c)]/1,08 & & \\
n) For Indifference Price Point (IDP) & & \\
[b*(g-c)]/1,08 & & \\
\hline
\end{tabular}

According to Optimal Price Point (OPP), the potential room income loss is 627.187,56 TL for July, and 706.911,31 TL for August. The price at the OPP point is the ideal price point according to the quality perceived by the customers, and the customers are willing to pay the price at this point, so the hotel business has lost a large amount of revenue. On the other hand, this pricing does not create any quality and idle capacity concerns.

According to the point of Marginal Cheapness (PMC), potential room sales revenue loss is $331.483,85$ TL in July and 565.936,31 TL in August. In other words, the room sales revenues may increase at least as much as these amounts. Also, in terms of yield management, it can be said that the prices at the point of marginal cheapness will maximize the customer turnover rate. Although the occupancy is low, setting a price below 144 TL in July and 159 TL in August may lead to a negative opinion on the quality of the service offered and result in lower operating revenues. Also, this may damage the brand value of the business. Therefore, pricing should be made within the specified price range (144-155 TL in July and 159-165 TL in August) even if occupancy decreases.

According to the Point of Marginal Expensiveness (PME), potential room sales revenue loss is 893.320,09 TL in July and 1.035.852,97 TL in August. So, room sales revenues may increase at this maximum amount. In other words, the prices at the point of marginal expensiveness will maximize the revenue. Also, pricing can be made up to 182 TL in July and 189 TL in August in periods of high occupancy in terms of yield management. 
According to the Indifference Price Point (IDP), potential room sales revenue loss is 494.120,89 TL in July and 659.919,64 TL in August. In other words, room sales revenues may increase at this average amount. In terms of yield management, customers will not show purchasing resistance, as the prices at this point provide information about the market price and comply with the reference price in the minds of customers in terms of willingness to pay.

Table 2 indicates that the hotel business lost room revenue at all points calculated. According to the interviews, the loss of income was due to the discounts provided repeat customers and timeshare vacation customers, and especially the commission paid to the agencies.

Travel agencies get a commission per customer from all-inclusive hotel businesses like other board types (Üngüren and Cengiz, 2009). The commission rate is generally 10\% (İçöz, 2001). But, the commission rate varies between 10-20\% in another source (Swain, 2014). However, especially summer resort hotels are selling their rooms to tour operators in a block selling and discounted in advance depending on the occupancy to guarantee their occupancy (Emeksiz and Yolal, 2013). Thus, tour operators provide a 25\%-60\% discount compared to the regular price (İçöz, 2001). But, tour operators also pay commissions to travel agencies that mediate their sales. Generally, tour operators pay $10 \%$ commission to wholesaler travel agencies and $15 \%$ commission to retail travel agencies (Ahipaşaoğlu, 2002). Also, hotels pay commissions for rooms sold through online sales channels such as Expedia, Booking, and Agoda. For example, according to a statement released by the online hotel reservation portal Booking.com, it gets 15\% commissions from hotel bookings through the website in Turkey. Moreover, Booking.com has stated that this commission rate is the lowest one (Hürriyet, 2017).

Today, many travel agencies offer their customers various services such as reservations, tour sales, ticket sales over the internet. Thus, they can reach more audiences without the time and environment limitation (Ansen and Firat, 2009). The Turkish Tourism Investors Association (TYD) Chairman Murat Ersoy has stated that the online hotel reservation portal commission demanded from the hotels in Istanbul reaches to the level of 50\%. He also has stated that these portals not only ring alarm bells but also have an extensive coverage by allocating a budget over $\$ 1$ billion only research and development. Additionally, he has emphasized that unless they make provision against these portals, the portals will get the level of $50 \%$ the reservation share within five years (Tourexpi, 2016).

Markus Luthe, CEO of The German International Hotel Association (IHA), has pointed out the monopolization of online distribution channels such as Booking and Expedia on hotels. He has stated that the commission rates of 8-15\% currently, but it will increase to $40 \%$ and even these rates are applying in Germany. He also stated that as the commission rates increase, the visibility of the hotels on these sites increases and therefore some hotels give commissions up $40 \%$ to increase visibility. Also, these sites affect the room prices in hotels 
and cause monopolization by setting current prices. Besides, there are notably lawsuits filed against online violations and monopolization in countries such as Germany, England and France (Daş, 2014).

According to the 2016 report submitted by the Priceline Group, which the Booking.com is affiliated to, to U.S. Securities and Exchange Commission (SEC); the company's net profit for 2016 is approximately 2 billion 135 million dollars (Hürriyet, 2017). Additionally, according to the instant survey conducted to participating hotels in the "travel, technology and digital marketing in hotels" event, it has been determined that the annual commission paid by participating hotels to online travel agencies is over 400,000 TL on average. According to the same survey results; the rate of the booking received by the hotels' web sites is below $10 \%$. As a solution, Erhan Kaya, the president of Hotel Linkage, has emphasized that the hotel has increased its website booking ratio to $35 \%$ with its Direct Booking Suite application. In this context, he has suggested that if they make the necessary investments on their web sites, they could reduce the commission costs by selling in the web sites (TurizmGünlüğü, 2017).

If reservations are received through hotels' websites and reservation portals, the commissions paid to travel agencies will decrease. So hotel businesses will gain a competitive price advantage by reducing the cost (Ansen and Firat, 2009). Therefore, the websites should be designed as user-friendly in terms of content, visuality, and ease of use. Also, hotel managers ought to establish a relationship which will make guests feel special themselves, send a thankyou mail to the guests who make a direct booking, and make a discount to the repeat guests (TurizmGüncel, 2015). Besides, if the hotel managers provide information about room pricing practices to customers who make reservations from hotel websites, customers' perception of price fairness increases, thus increasing their willingness to pay. For example, Intercontinental Hotel Group encourages its customers to book on the hotel's website, guaranteeing the best available rate (Choi and Mattila, 2004).

Since hotel products are not frequently purchased, internal reference price information becomes less accessible in the minds of the customer. Hence, they mostly consider the external reference price of the competitors in their price decisions. Unlike third-party intermediaries (e.g. Expedia.com, Orbitz.com and Travelocity.com), a hotel website does not compile competing for hotel prices so that we can draw the attention of hotel customers from an external reference price of the competitors. Thus, there are no conflicts about price unfairness in the minds of customers (Choi and Mattila, 2004; Karande and Magnini, 2011).

In addition to their web sites, hotel businesses should reach customers by using all social media channels. Also, the TripConnect application on the Tripadvisor website encourages the customers to purchase directly. Besides, the online booking manager should be employed in businesses to increase the visibility and online sales of the hotel by using global distribution channels such as Amadeus, Galileo, Saber, and Worldspan (TurizmGüncel, 2015). Alterna- 
tively, hotel managers ought to understand customer arrival sources and work with online travel agencies. But travel agencies should not be allowed price setting and restrictions and should establish a legal framework. The relevant legislation is going to be established in Europe within 3 years (Daş, 2014).

A new reservation portal which can be integrated into small search engines can reduce commission rates from $50 \%$ to less than $10 \%$ (Tourexpi, 2016). Besides, Protel Online, developed by Protel, offers internet booking engine, channel manager and global distribution system. With the internet booking engine, hotel businesses can get reservations through their websites without the need for any intermediaries and paying commissions. Through the channel manager application, hotel managers can make price updates quickly, prevent reservation conflicts and overbooking. With the global distribution system, hotel businesses can join in the pool of all intermediary companies in the sector (Tourismtoday, 2016).

In summary, hotel businesses can reduce the commission costs by increasing their sales by developing their web sites, creating a customer loyalty program, employing an online reservation manager, participating in global distribution systems, establishing a common portal or benefiting from the automation systems developed as an alternative.

\section{Conclusions, Implications and Limitations}

This study showed that the hotel business lost room revenue at all points calculated. The hotel business suffered a potential loss of $35-40 \%$ because of the high occupancy rate in July and August. Also, the hotel business could possibly gain room sales revenues as a minimum of 331.483,85 TL and a maximum of $893.320,09 \mathrm{TL}$ in July, and a minimum of 565.936,31 TL and a maximum of 1.035.852,97 TL in August. Thus, the pricing policies of the hotel business were set low enough to harm the negative quality perception and brand value.

According to the interviews, the loss of income was due to the discounts provided for repeat customers and timeshare vacation customers, and especially the commission paid to the agencies. The hotel business could have room sales revenues much more than the actual room sales revenues, especially if the travel agency commission expenses can be reduced. The study has both practical and theoretical implications.

\section{Practical Implications}

In terms of practical implications, the practitioners (hotel managers) may use the PSM method in determining the price threshold limits, identifying the most suitable room price depending on the customers' quality perceptions and willingness to pay. Also, the practitioners (hotel managers) can use the price points determined by the PSM method in yield manage- 
ment in a way that maximizes the customer turnover rate or maximizes profit by taking into account the brand value and capacity utilization rates of the hotel businesses.

It is inevitable for hotel businesses to use an intermediary in sales. However, travel agency commission expenses can be reduced. In this regard, the websites should be designed as user-friendly in terms of content, visuality, and ease of use. Also, the practitioners (hotel managers) should make a discount to the repeat guests, establish a special relationship with guests who make a direct booking and send a thank-you mail after the reservation. In addition to web sites, the practitioners (hotel managers) need to reach customers by using all social media channels. Besides, the practitioners (hotel managers) should employ an online booking manager. Also, the practitioners (hotel managers) should use the TripConnect application on the Tripadvisor website, establish a common portal or benefit from the automation systems developed as an alternative. Moreover, it is necessary to understand the sources of customer arrival, to work with online travel agencies if needed, but not to allow price setting and restrictions and to establish a legal framework.

When consumers know more information about a product, price threshold limits, and price perceptions will change. Besides, if customer satisfaction or customer loyalty increases, price threshold limits will show a tendency to increase. Therefore, practitioners (hotel managers) should follow policies that increase customer satisfaction and improve quality. Also, practitioners (hotel managers) should conduct price research to understand customer value perceptions correctly and make accurate pricing. Furthermore, when customers know more information about pricing practices, perceptions of price unfairness will change. So, practitioners (hotel managers) should provide information about room pricing practices to customers who make reservations from hotel websites.

\section{Theorotical Implications}

In terms of the theoretical implications of the study, price is a criterion indicating the willingness to pay for the product/service for potential customers. Today the tourists have a high price sensitivity, especially in terms of hotel businesses. Thus, the willingness to pay and price sensitivity should be taken into consideration when making a pricing decision. Also, the customers are primarily looking for signs of product/service quality in price, so the wrongly adjusted product/service price can affect the decision to buy. On the other hand, customers may pay more for the product/service according to their perceived value. In the research, price sensitivity measurement (PSM) method is used to solve such constraints and problems.

The PSM method is a simple survey tool to pre-measure the price sensitivity of customers and provide reliable information about consumers' reactions to prices. Instead of using a gut feeling or trial and error to determine the right price for products/services, a hotel/restaurant 
owner can use the PSM method for pricing without risking losing market share or revenue.

Since pricing is made by taking into consideration factors such as price sensitivity, willingness to pay and perception of value by price sensitivity measurement method, it eliminates the possible demand change sensitivity and price unfairness which may occur as a result of pricing in terms of yield management. The method also provides information about minimum and maximum prices which can be determined based on demand changes. On the other hand, hotel businesses can determine the optimal price by depending on the quality and value perception of the customers; thus they can use their limited capacity more efficiently so that they can maximize yield.

\section{Limitations and Further Research}

The main limitation of the research is that the analysis was carried out in a single hotel business and on a small sample size. The content of an all-inclusive pension may differ between hotel businesses. However, while determining the room price with the PSM method, the current services of the hotel business were taken into account in the study. In future studies, more general results can be obtained by repeating the research in different hotels and on a larger sample.

Price research was conducted during the peak season. In future studies, price comparison can be made according to the occupancy rates in different seasons. Also, their effectiveness can be measured using different price research methods simultaneously.

Price thresholds and perceptions change when customers get information about the product, or customer satisfaction and customer loyalty increases. In this context, price researches can be conducted according to customer profiles and awareness levels. Also, the effects of using the optimal price determined by the PSM method in dynamic pricing on revenue maximisation can be measured. Besides, by including the customer profitability analysis method in the price research process, the customer groups with the highest revenue and the most cost can be determined. Thus, the right customer decision can be more effective in terms of yield management.

Peer-review: Externally peer-reviewed.

Conflict of Interest: The authors have no conflict of interest to declare.

Grant Support: The authors declared that this study has received no financial support. 


\section{References}

Abrate, G., Fraquelli, G. and Viglia, G. (2012). Dynamic pricing strategies: Evidence from European hotels. International Journal of Hospitality Management, 31 (1), 160-168.

Abrate, G., Nicolau, J. L. and Viglia, G. (2019). The impact of dynamic price variability on revenue maximization. Tourism Management, (74), 224-233.

Ahipaşaoglu, H. S. (2002). Seyahat acentacılı̆̆l ve tur operatörlüğ̈̈ [Travel agency and tour operator]. Eskişehir: Anadolu University Open Education Faculty Publishing.

Ansen, E. N. and Fırat, A. (2009). Turizm işletmelerinde elektronik pazarlama: Antalya "A grubu seyahat acentaları örneği [Electronic marketing in tourism businesses: The case of Antalya Province "a class travel agencies"]. Journal of Entreprenurship and Development, 4 (2), 117-134.

Ayık, T., Benetatos, T. and Evagelou, I. (2013). Tourist consumer behaviour insights in relation to all inclusive hotel resorts: The case of Antalya. Journal of Tourism Research, 7, 109-123.

Balc1, A. (2011). Sosyal bilimlerde araştırma yöntem, teknik ve ilkeler [Research methods, techniques and principles in social sciences]. Ankara: Pegem Academy.

Bitran, G. and Caldentey, R. (2003). An overview of pricing models for revenue management. Manufacturing \& Service Operations Management, 5 (3), 203-229.

Blythe, J. (2005). Essentials of marketing. England: Pearson Education.

Burnett, J. (2008), Core concepts of marketing. Switzerland: A Global Text.

Ceylana, H. H., Koseb, B., Aydin, M. (2014). Value based pricing: A research on service sector using Van Westendorp Price Sensitivity Scale. Procedia - Social and Behavioral Sciences, 148, 1-6.

Chhabra, S. (2015). Determining The Optimal Price Point: Using Van Westendorp's Price Sensitivity Meter. In S. Chatterjee, N. Singh, D. Goyal, \& N. Gupta (Eds.), Managing in Recovering Markets. (pp.257-270), India: Springer Proceedings in Business and Economics.

Choi, S. and Mattila, A. S. (2004). Hotel revenue management and its impact on customers' perceptions of fairness. Journal of Revenue and Pricing Management, 2 (4), 303-314.

Çetiner, E. (2002). Konaklama işletmelerinde muhasebe uygulamaları [Accounting practices in hospitality businesses]. Ankara: Gazi Publishing.

Daş, S. (2014). Online acenteler tekelleşiyor, komisyon oranları yüzde 40'lara tırmanacak [Online agencies become monopolized, commission rates will climb to 40 percent], Retrieved from: http://turizmguncel.com/haber/online-acenteler-tekellesiyor-komisyon-oranlari-yuzde-40'lara-tirmanacak-h21262.html, 01.02.2018.

Desmet, P. (2016). Effectiveness of measures assessing response to price information. Journal of Product \& Brand Management, 25 (7), 676-686.

Dominique-Ferreira, S. and Antunes C. (2020). Estimating the price range and the effect of price bundling strategies: An application to the hotel sector. European Journal of Management European Journal of Management, 29 (2), 166-181.

Donatello, M. C. (2013). Assessing Audiences' Willingness to Pay and Price Response for News Online. (doctoral dissertion), University of North Carolina, Chapel Hill.

Dong, X., Zhang, B., Wang, B. and Wang Z. (2020). Urban households' purchase intentions for pure electric vehicles under subsidy contexts in China: Do cost factors matter?, Transportation Research Part A, 135, 183-197. 
Emeksiz, M., Gürsoy, D. and İçöz, O. (2006). A yield management model for five-star hotels: computerized and non-computerized implementation. Hospitality Management, 25 (4), 536-551.

Emeksiz, M. and Yolal, M. (2013). Konaklama hizmetleri ve organizasyonu [Accommodation services and organization], in Gürel, D. A. (Ed.), Otel İşletmelerinde Konaklama Hizmetleri [Accommodation Services in Hotel Businesses], Eskişehir: Anadolu University Open Education Faculty Publishing.

Farrel, K. and Whelan-Ryan, F. (1998). Yield management: A model for 1mplementation. Progress In Tourism and Hospitality Research, 4 (3), 267-277.

Jones, P. A. (2013). Revenue management, hospitality finance, revenue and IT professionals (HOSPA), Bournemouth: Practition Series.

Jones, P. and Hamilton, D. (1992). Yield management: putting people in the big Picture. The Cornell Hotel and Restaurant Administration Quarterly, 33 (1), 89-95.

Grigsby, M. (2015). Analytic choices about pricing 1nsights. Marketing Insights, 27 (2), $38-43$.

Hague, N. (2009). The problem with price. The Journal of Professional Pricing, 18 (3),28-33.

Hanks, R. D., Cross, R. G. and Noland, R. P. (2002). Discounting in the hotel industry: A new approach. Cornell Hotel and Restaurant Administration Quarterly, 43 (4), 94-103.

Harmon, R., Raffo, D. and Faulk, S. (2003). Incorporating price sensitivity measurement into the software engineering process, Kocaoglu, D. and Anderson, T. (Eds.), in PICMET: Portland international conference on management of engineering and technology management for reshaping the world, (pp. 316-323), Portland: IEEE Publishing.

Harmon, R. R., Unnil, R. and Anderson, T. R. (2007). Price sensitivity measurement and new product pricing: A cognitive response approach. In PICMET: Portland international conference on management of engineering \& technology, (pp.1961-1967), USA: IEEE Publishing.

Hidalgo, H. A. (2017). Market potential of Pasteurized Coconut Water in the Philippine Beverage Industry. International Journal on Advanced Science Engineering Information Technology, 7 (3), 898-903.

Hürriyet. (2017). Booking.com Türkiye'de ne kadar komisyon aldığını açıkladı [Booking.com how much commission announced that it had in Turkey], Retrieved from: http://www.hurriyet.com.tr/booking-comyetkililerinden-onemli-aciklamalar-40418792, (accessed 01.02. 2018).

Hoffman, K. D. and Bateson, J. E. (2010). Services marketing: concepts, strategies, \& cases. USA: SouthWestern Cengage Learning.

İçöz, O. (2001). Turizm işletmelerinde pazarlama ilkeler ve uygulamalar [Marketing principles and practices in tourism businesses]. Ankara: Turhan Publishing.

Jallat, F. and Ancarani, F. (2008). Yield management, dynamic pricing and CRM in telecommunications. Journal of Services Marketing, 22 (6), 465-478.

Kahneman, D., Knetsch, J. L. and Thaler, R. H. (1986). Fairness and the assumptions of economics. The Journal of Busines, 59 (4), S285-S300.

Karande, K. and Magnini, V. P. (2011). The relative use of contextual and temporal reference price components in hotel and airline purchases. Journal of Hospitality \& Tourism Research, 35 (1), 119-141.

Khandker, V. and Joshi, K. P. (2019). Price determination for 4G service using price sensitivity model in India, Journal of Revenue Pricing Management, 18, 93-99.

Kızılot, Ş. (2008). Turizmde farklı KDV oranları ve uygulama esasları [Different VAT rates and application principles in tourism]. Journal of Yaklaşım, 181, 1-5.

Kimes, S. E. (1989). The basics of yield management. Cornell Hotel and Restaurant Administration Quarterly, 30 (3), 14-19. 
Kimes, S. E. and Wirtz, J. (2002). Perceived fairness of demand-based pricing for restaurants. Cornell Hotel and Restaurant Administration Quarterly, 43 (1), 31-37.

Koide, T. and Ishii, H. (2005). The hotel yield management with two types of room prices, overbooking and cancellations. International Journal Of Production Economics, 93, 417-428.

Kotler, P. and Keller, K. L. (2012). Marketing management. New Jersey: Pearson Education.

Lewis, R. C. and Shoemaker, S. (1997). Price-sensitivity measurement: A tool for the hospitality industry. Cornell Hotel And Restaurant Administration Quarterly, 38 (2), 44-54.

Lieberman, M. (2015). Pricing research: A new take on the van westendorp model. Quirk's Marketing Research Review, 2, 1-5.

Lipovetsky, S., Magnan, S. and Polzi, A. Z. (2011). Pricing models in marketing research. Intelligent Information Management, 3 (5), 167-174.

Mattila, A. S. and Choi, C. (2014). An analysis of consumers' reactions to travel websites' discrimination by computer platform. Cornell Hospitality Quarterly, 55 (2), 210-215.

Mirze, S. K. (2010). İşetme [Business management]. İstanbul: Literatür Publishing.

Monroe, K. B. and Cox, J. L. (2001). Pricing practices that endanger profits. Marketing Management, 10 (3), 42-46.

Netessine, S. and Shumsky, R. (2002). Introduction to the theory and practice of yield management. INFORMS Transactions on Education, 3 (1), 34-44.

Okumuş, F. (2004). Implementation of yield management practices in service organisations: Empirical findings from a major hotel group. Service Industries Journal, 24 (6), 65-89.

Özel, Ç. H., Emeksiz, M., Yolal, M. and Yılmaz, H. (2012). Odalar bölümü yönetimi [Rooms division management]. Eskişehir: Anadolu University Open Education Faculty Publishing.

Parsa, H. G. and Njite, D. (2004). Psychobiology of price presentation: An experimental analysis of restaurant menus. Journal of Hospitality \& Tourism Research, 28 (3), 263-280

Raab, C., Mayer, K., Kim, Y.-S. and Shoemaker, S. (2009a). Price-sensitivity measurement: A tool for restaurant menu pricing. Journal of Hospitality \& Tourism Research, 33 (1), 93-105.

Raab, C., Mayer, K., Shoemaker, S. and Ng, S. (2009b). Activity-based pricing: can it be applied in restaurants?. International Journal of Contemporary Hospitality Management, 21 (4), 393-410.

Roll, O., Achterberg, L. H., and Herbert, K. G. (2010). Innovative approaches to analyzing the price sensitivity meter: Results of an international comparative study. Laurea Publications A, 72, 181.

Salamandic, E., Alijosiene, S. and Gudonaviciene, R. (2014). Price sensitivity measurement depending on brand awareness: A case of Ziede brand. Procedia-Social and Behavioral Sciences, 156, 473-478.

Salamandic, E., Alijosiene, S. and Gudonaviciene, R. (2015). Comparing the price sensitivity measurement effectiveness for new vs. established brands. Trends Economics and Management, IX (22), 38-46.

Smith, G. E. and Nagle, T. T. (2002). How much are customers willing to pay?. Marketing Research, 14 (4), 20-25.

SMS. (2008). What should we charge? setting price, Retrieved from: http://www.satmansys.com, (accessed 24.11.2016).

Swain, S. K. (2014). Travel agency and tour operations management. India: Pondicherry University Publishing. 
Tourexpi. (2016). TYD Başkanı Murat Ersoy: ‘2016 yılında tur operatörleri rehavete kapıldı' [TYD President Murat Ersoy: 'Tour operators were complacent in 2016']. Retrieved from: http://www.tourexpi.com/trtr/news/tyd-baskani-murat-ersoy-2016-yilinda-tur-operatorleri-rehavete-kapildi-128383.html, (accessed 01.02. 2018).

Tourismtoday. (2016). Otellerin satışları artacak [Hotel sales will increase], Retrieved from: http://www. tourismtoday.net/otellerin-satislari-artacak-50071h.htm,(accessed 01.02.2018).

Travis, K. M. (1982). Price sensitivity measurement technique plots product price vs. quality perceptions. Marketins News, 14, 6-7.

Turizmgüncel. (2015). Oteller direkt rezervasyonların sayısını arttırmak için neler yapmalı? [What should hotels do to increase the number of direct bookings?], Retrieved from: http://turizmguncel.com/haber/oteller-direkt-rezervasyonlarin-sayisini-arttirmak-icin-neler-yapmali-h22350.html, (accessed 21.11.2016).

Turizmgünlüğü. (2017). Otellerin komisyon maliyeti nazıl azalır? [How does the commission cost of hotels decrease?], Retrieved from: https://www.turizmgunlugu.com/2017/11/01/ otellerin-komisyon-maliyetinasil-azaliir/> (accessed 20.01.2018).

Üngüren, E. and Cengiz, F. (2009). Her şey dâhil sisteminin pazarlama karması unsurları kapsamında değerlendirilmesi [Evaluation of the all-inclusive system within the scope of marketing mix elements]. in 3. Ulusal Gastronomi Sempozyumu ve Sanatsal Etkinlikler Kitabı [3rd National Gastronomy Symposium and Artistic Activities Book], (pp. 54-65) Antalya: Akdeniz University.

Weiner, J. L. (2002). Applied pricing reseach. In Proceedings of The Sawtooth Software Conference, (pp. 111-122) Sawtooth Software, WA: Sequim.

Westendorp, P. H. (1976). NSS-Price sensitivity meter (PSM)- A new approach to study consumer perception of price. in Proceedings of the ESOMAR Congress, Venice, 139-167. 
